5. Sczesny, S., Formanowicz, M., \& Moser, F. (2016). Can Gender-Fair Language Reduce Gender Stereotyping and Discrimination? Retrieved from: https://www.frontiersin.org/articles/10.3389/fpsyg.2016.00025/full (accessed 5 September 2020).

6. Sobetska, N. V. (2016) Vzhyvannja feminityviv jak projav ghendernoji kuljturzhyvannja feminityviv jak projav ghendernoji kuljtury [Application of Feminityves As a Manifestation of Gender Culture]. Young Scientist, vol. 12(1), no. 40, pp. 375-378. Retrieved from: http://molodyvcheny.in.ua/files/journal/2016/ 12.1/86.pdf (accessed 20 August 2020).

7. Sosnowski, W. P., \& Satoła-Staśkowiak, J. (2019) A contrastive analysis of feminitives in Bulgarian, Polish and Russian. Cognitive Studies / Études cognitives (electronic journal), no. 1922, pp. 1-12. Retrieved from: https://www.researchgate.net/ publication/338623062_A_CONTRASTIVE_ANALYSIS_OF_FEMINITIVES_IN_B ULGARIAN_POLISH_AND_RUSSIAN (accessed 25 August 2020).

8. Stahlberg, D., Braun, F., Irmen, L., \& Sczesny, S. (2007). Representation of the sexes in language. Retrieved from: https://www.researchgate.net/publication/ 291783641_Representation_of_the_sexes_in_language (accessed 22 August 2020).

\title{
TO THE ISSUE OF TRANSLATION SOME ENGLISH MILITARY TERMS IN NATIONALITY CONTEXT
}

\section{Roman Serhiienko ${ }^{1}$ Yulia Denysyuk ${ }^{2}$}

DOI: https://doi.org/10.30525/978-9934-588-84-6-9

Due to the historically developed ambiguous interpretation of military terms in different countries there are some difficulties in translating them. This is especially relevant for the terminology on English, which is important for successful international cooperation of Ukraine with the NATO countries. This causes a misunderstanding of the partner, and in the military sphere it can lead to serious consequences. Therefore, it is important to consider the lexical features of the translation of some military terms related to weapons and tactics, namely: «missile troops and artillery», "ground forces», to offer options for translation and interpretation of certain military terms in different contexts.

\footnotetext{
${ }^{1}$ Hetman Petro Sahaidachnyi National Army Academy, Ukraine

${ }^{2}$ Hetman Petro Sahaidachnyi National Army Academy, Ukraine
} 
A significant contribution to the streamlining of the translation of military terms was made by Nelyubin L. in the textbook «Military translation. General course» (1981), where the features of military translation were considered, military terms were classified and the rules of their translation were indicated. However, over the years, new weapons and tactics have emerged. In 2008, the textbook «Fundamentals of Military Translation: (English)» by V. Balabin was published, which updated translations of military terminology and provided it for new military terms. However, it should be noted that the textbook focuses on the translation of military terms of the US Armed Forces, while the translation of military terms and names characteristic of the Armed Forces of Ukraine was left out of the authors' attention. Notice that military terminology regarding armaments, tactics of action of units of the USSR Armed Forces are documented in the Field Statutes of the US Armed Forces: FM 100-1, FM 100-2, FM 100-3.

Thus, there is the issue raised about systematization of the translation military terms from Ukrainian into English that would be a contribution to the harmonization of military terminology of the Armed Forces of Ukraine and the Armed Forces of NATO countries.

Consider such a common concept in the Armed Forces of Ukraine as «missile troops and artillery». By this term we mean artillery units equipped with mortars, artillery barrels: guns, howitzers, etc., multiple rocket launchers, as well as units of missile troops armed with tactical missile systems (9K79) and in the recent past operational and tactical missiles (9K72).

Units and subdivisions equipped with operational-strategic ballistic missiles in the former USSR belonged to a separate type of the Armed Forces - strategic missile forces.

It should be noted that in Ukrainian Armed Forces there are the terms «artillery» which generally includes mortars, artillery and rocket artillery, and the term «missile forces», which means units armed with complexes of tactical, operational and tactical missiles.

Consider further the interpretation of these terms in specialized sources in relation to the armed forces of other countries, including the United States. One of these is the mentioned textbook of military translation by L. Nelyubin. According to this textbook, US artillery is divided into «field artillery» and "air-defense artillery». Let's consider further what the term «field artillery» means. According to the content of the devoted to artillery section of the textbook, the term «missile troops and artillery», that used 
in the Armed Forces of Ukraine, means the same as the term «field artillery» in the Armed Forces of the United States [1].

At the same time, it is interesting to note that in the textbook of military translation L. Nelyubin the term «field artillery» is recommended to translate literally as «polevaya artileriya» («field artillery»), presumably to emphasize that we are talking about the armed forces of another state (USA) [1]. A similar situation occurs in the official publications of the US Armed Forces on the organization and armament of the Armed Forces of the former USSR. Thus, in accordance with the US Armed Forces FM 100-2-3 «The Soviet Army: Troops, Organization, and Equipment», which deals with the structure and armament of the Armed Forces of the former USSR, the term «raketnye voiska i artileriya» («missile troops and artillery») is translated as «Missile Troops and artillery», - a literal translation of the original term [7]. This also, in our opinion, emphasizes belonging to the armed forces of another state - a potential enemy for that time.

Consider the translation options provided by widely used online dictionaries. For example, The Oxford Essential Dictionary of the U.S. Military interprets the term "field artillery» as "artillery consisting of artillery, missile or missile ground installations that are sufficiently mobile to escort field troops. Field artillery is divided into three groups according to the caliber of ammunition. Light field artillery uses ammunition of $120 \mathrm{~mm}$ or less; the environment uses $121-160 \mathrm{~mm}$, and heavy artillery uses ammunition 161-210 mm or more» [3].

The DOD Dictionary of Military and Associated Terms defines the term «field artillery» (FA) as «equipment, supplies, ammunition and personnel involved in the use of artillery, missile or missile ground installations» [4].

Online dictionary Multitran.ru translates the term «polevaya artileriya» («field artillery») literally - as «field artillery». The term «field artillery missile battalion» has been translated as a «battalion of operationaltactical missiles», which once again emphasizes that the term «field artillery» covers tactical and operational-tactical missiles. However, it should be noted that it is not emphasized to the armed forces of which country these concepts are applied. In another direction of translation, the term «raketnye voiska i artileriya» («missile troops and artillery») offers different literal translations: «missile forces and artillery», «missile troops and artillery», «rocket troops and artillery» [5]. 
Collins' online glossary defines the term «field artillery», mainly explaining the «field» component - artillery capable of deploying to support troops at the front line, mobile artillery capable of firing ground component [6].

Considering the term «missile troops and artillery» one cannot ignore the term «missile», as well as the term «missile troops», inherent in the Armed Forces of the former Soviet Union. The term «rocket» is translated by the following equivalents: rocket, missile. In order to more accurately translate the types and names of weapons of the Armed Forces of Ukraine, and to obtain a translation that will be understandable and will not shock the ear of native speaker, we considered the semantics of these terms. The research showed that the presence of a flight control system on board the rocket (jet projectile) determines that the term «missile» should be used for translation, if not - the term «rocket» would be more preferable.

Consider the translation of another term - the word combination «Land Forces», which denotes the ground component of the Armed Forces. In the United States it is translated as "Army». At the same time, in the abovementioned FM in the USSR and Warsaw Pact countries it was translated into English as «Land Forces». It should be noted that in Ukraine the terms «army aviation», «army air defense» are used, where the component «army» means belonging to the Land Forces.

Based on above we have two versions of the translation of the term «Sukhoputnye voiska» («Land Forces»), which correctly reflect for English-speaking readers the essence of this concept: «Army» and «Land Forces».

Note that the translations, in which the object and subject are the United States and the former Soviet Union, reflect the fact that these countries were antagonists and considered each other's armed forces as a possible enemy. This, in our opinion, prompted translators to contrast similar concepts in another country by translating the concept into a different term from that adopted in their own country. For example, the ground component of the US Armed Forces is denoted by the term "Army», while in FM 100-2-3 the ground component of the USSR Armed Forces is translated by the term «Land Forces». Thus, for the US Armed Forces servicemen as well as US citizens involved in the Armed Forces the term «Land Forces» is likely to evoke a sense of enemy, adversary. The term «Army» for such reasons will subconsciously evoke the feeling that it is a friendly force. 
In order to justifiably give preference to one or another version of the translation of a term, it is also necessary to investigate how similar terms are translated into English in NATO member countries. Such the investigation proved that in former Warsaw Pact countries the term «land Forces» is used, but in the contrary in countries which had become NATO members before the USSR dissolution the armed forces land component was denoted as «Army».

In conclusion, we emphasize that for the successful implementation of military translation it is necessary not only be competent in the relevant foreign language and military terminology, but also to have sufficient knowledge in the military issues.

\section{References:}

1. Neliubin, L. L., Dormidontov, A. A., Vasilchenko, A. A. (Ed.) (1981). Uchebnik voiennoho perevoda: Anhliiskii yazyk [Military Translation Textbook: English]. Moskva: Voenizdat. (in Russian)

2. Balabin, V. V., Lisovskyi, V. M., Chernyshov, O. O. (Ed.). (2008). Osnovy viiskovoho perekladu: anhliiska mova [Basics of military translation: English]. Kyiv: Lohos. (in Ukrainian)

3. The Oxford Essential Dictionary of the U.S. Military. URL: $\quad$ https://www.oxfordreference.com/view/10.1093/acref/9780199891580.001.0001/ acref-9780199891580

4. DOD Dictionary of Military and Associated Terms. URL: https://www.jcs.mil/ Portals/36/Documents/Doctrine/pubs/dictionary.pdf

5. Slovar Multytran. URL: https://www.multitran.com

6. Collins English Dictionary URL: https://www.collinsdictionary.com

7. FM 100-2-3. The Soviet Army: Troops, Organization, and Equipment. URL: https://fas.org/irp/doddir/army/fm100-2-3.pdf 